\title{
Gastritis: An Update in 2020
}

Massimo Rugge, $M D^{1,2, *}$

Kentaro Sugano ${ }^{3}$

Diana Sacchi ${ }^{1}$

Marta Sbaraglia ${ }^{1}$

Peter Malfertheiner ${ }^{4}$

\author{
Address \\ ${ }^{1}$ Department of Medicine (DIMED), Surgical Pathology \& Cytopathology Unit, \\ University of Padua, Via A. Gabelli, 61, 35121, Padova, Italy \\ ${ }^{*}, 2$ Veneto Tumor Registry (RTV), Veneto Regional Authority, Padova, Italy \\ Email: massimo.rugge@unipd.it \\ ${ }^{3}$ Department of Medicine, Jichi Medical University, Tochigi, Japan \\ ${ }^{4}$ Department of Internal Medicine II, Hospital of the Ludwig Maximilian University \\ of Munich, Munich, Germany
}

Published online: 26 August 2020

(C) The Author(s) 2020

This article is part of the Topical Collection on Stomach

Keywords Atrophic gastritis • OLGA staging • Gastric oncogenesis • Intestinal metaplasia - Helicobacter pylori . Spasmolytic peptide expressing mucosa

\section{Abstract}

Purpose of review The gastritis constellation includes heterogeneous clinicopathological entities, among which long-standing, non-self-limiting gastritis, mainly due to Helicobacter pylori infection, has been epidemiologically, biologically, and clinically linked to gastric cancer development (i.e. "inflammation-associated cancer"). This review illustrates the updated criteria applied in the taxonomy of gastritis (Kyoto classification), elucidates the biological rationale for endoscopy biopsy sampling (heterogeneity of gastric mucosa), and finally reports the results of long-term follow-up studies supporting the reliability of biopsy-based gastritis staging as predictor of gastritis-associated cancer risk.

Recent findings By assuming gastric atrophy as the "cancerization field" where (nonsyndromic) gastric cancer mostly develops, recent long-term follow-up studies consistently demonstrate the prognostic impact of the gastritis OLGA staging system.

Summary Helicobacter pylori eradication is the leading strategy in the primary prevention of gastric cancer. In a multidisciplinary dimension of secondary cancer prevention, the OLGA staging system reliably ranks the patient-specific cancer risk, thus providing the clinical rationale for a tailored follow-up strategy. 


\section{Introduction}

The "gastritis" label is extensively (but inappropriately) applied to a spectrum of clinical symptoms relating to the upper abdomen, and the epigastrium in particular. The correct medical definition for this cluster of symptoms is dyspepsia. More strictly speaking, in the absence of organic disorders, the various combinations of upper digestive symptoms (e.g. bothersome postprandial fullness, early satiation, epigastric pain, and epigastric burning) should be defined as functional dyspepsia. There is an update on the (sub)types of functional dyspepsia at the Rome IV conference $[1,2]$.

At endoscopy, gastritis is described as any reddening or edema of the gastric mucosa, but neither of these endoscopic features is specific or exclusive to mucosal inflammation. A Japanese study on the accuracy of standard endoscopic imaging for the detection of $H$. pylori infection reported accuracy of $89 \%$ for nodularity and $77 \%$ for mucosal swelling [3].

The endoscopic assessment of gastritis has advanced significantly in recent times thanks to the use of high- definition endoscopy and virtual chromoendoscopy (narrow-band imaging [NBI], blue light imaging [BLI], and linked color imaging [LCI]) [4-6]. An endoscopic classification of gastritis has been proposed in Japan, but important steps in the validation process are still needed before it can be more generally accepted outside Japan [7].

The endoscopic detection and interpretation of gastric atrophy poses the greatest challenge. Although the combined use of high-definition endoscopy and virtual chromoendoscopy has significantly improved the accuracy of endoscopic assessments, the consistent implementation of these new technologies entails a steep learning curve, and they are still operator-dependent $[8,9]$.

In a recent study involving magnifying endoscopy combined with NBI, the authors reported that vascular architecture can detect premalignant gastric conditions accurately $(88 \%)$, and better than the serum pepsinogen I/II ratio (74\%) [10].

\section{Gastritis: Classification criteria}

From the clinical and pathological perspective, gastritis is defined as "acute" or "chronic." These two terms are commonly intended as synonymous with selflimiting or non-self-limiting, respectively. The temporal parameter used to distinguish acute from chronic diseases is largely subjective, and many "chronic" asymptomatic diseases may occasionally develop "acute" symptoms.

Equally questionable is the distinction between acute and chronic gastritis based on cellular inflammatory infiltrate: lymphocytes (typically associated with chronic inflammation) may prevail in some acute (i.e. self-limiting) forms of gastritis (lymphocytic gastritis), and granulocytes (typically associated with acute inflammatory lesions) can be found in chronic (i.e. non-self-limiting) inflammatory gastric diseases (e.g. H. pylori gastritis) (Figs. 1a, b and 2).

As recently acknowledged in the Kyoto global consensus report, the most valid gastritis classification relies on etiology. Leaving aside the (far from negligible) number of mucosal inflammations of unknown etiology, the agents involved in the etiology of gastritis can be gathered into two main groups: environmental agents (which may or may not be transmissible), and hostrelated, non-transmissible agents. The two etiopathogenic situations may overlap (Table 1). The etiological classification of gastritis (with minor adjustments to the Kyoto proposal) is shown in the table [11••, 12-14].

Excluding a false-negative $H$. pylori result remains a special challenge. For this purpose, marked reactive changes in both the antral and oxyntic mucosa need 

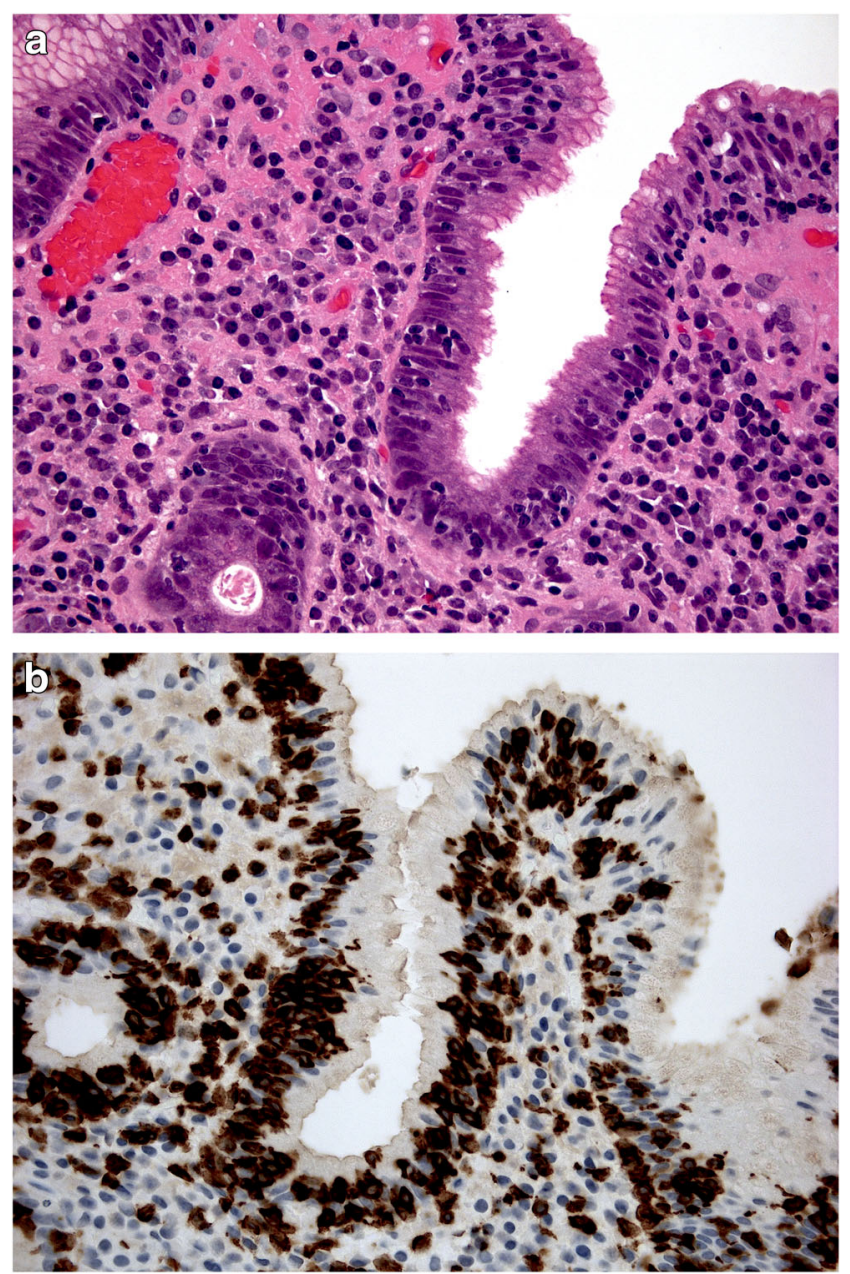

Fig. 1. a, b Lymphocytic gastritis: high-grade mononuclear lymphocytic infiltrate within the lamina propria, in a gastric biopsy sample obtained from antral mucosa; intra-epithelial lymphocytes are also shown. (a: Hematoxylin-eosin, original magnification $\times 40$ ). In the same biopsy sample, the CD3-immunostain clearly documents the high-grade intra-epithelial lymphocytic infiltrate. (b: CD3 immunostain, original magnification $\times 40$ ).

to be interpreted in the context of atrophy of other etiologies, or use of a proton pump inhibitor (PPI) [15]. El Zimaity et al. reported that H. pylori may only be found in parietal cells in patients on PPI. This is a rather exceptional situation and is not used as a criterion for assessing H. pylori-related gastritis. The differential diagnosis should include lymphocytic gastritis, vasculitis, granulomatous diseases, inflammatory bowel disease, viral infections, and other bacterial diseases. It is only after excluding all of these forms that the term " $H$. pylorinegative gastritis" should be considered [15-19, 20•].

\section{Gastritis: 2020 definition}

By definition, a diagnosis of gastritis requires the histological detection of inflammatory cells within the lamina propria. Leukocytes may also penetrate 


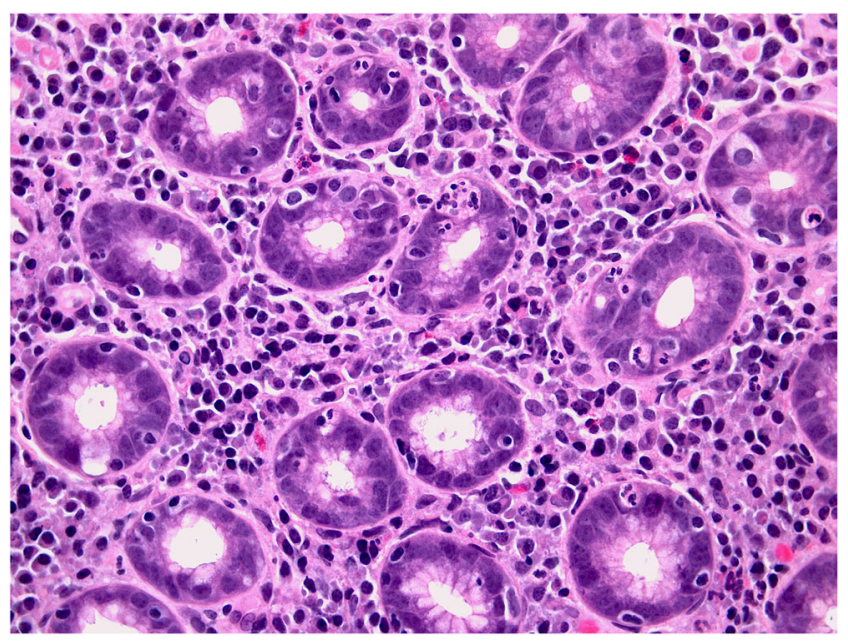

Fig. 2. Helicobacter pylori gastritis: the picture shows the high-grade granulocytic infiltrate within the lamina propria and inside the gastric glans (so-called active inflammation). (Hematoxylin-eosin, original magnification $\times 40$ ).

the glandular lumen and/or spread down into the submucosa. The topography, severity, and cellularity of the inflammatory lesions might sometimes enable us to distinguish between different etiological variants of gastritis. Leaving aside the cellular profile of the "inflammatory population," gastritis can be divided into two main forms, non-atrophic and atrophic. The need to distinguish between the two is crucially related to the different cancer risk associated with these two histological variants.

Non-atrophic gastritis exhibits mucosal damage that can even be extensive and/or severe, and may recover with trivial residual sequelae, or progress to atrophic phenotypes.

Atrophic gastritis is usually long-standing, and not self-limiting, and results from noxious agents that markedly alter the resident population of the gastric glands (i.e. oxyntic glands in the corpus/fundus, mucosecreting glands in the antral mucosa). In both these mucosal compartments, atrophy is defined as a "loss of native glandular units" [21, 22].

Atrophy may result from a loss of native glands, replaced by fibrosis (nonmetaplastic atrophy), or a focal or extensive replacement of the native gland population by metaplastic glands. Metaplastic atrophy may feature two phenotypes: intestinal metaplasia (IM), affecting the mucosecreting glands (Fig. 3), and pseudo-pyloric metaplasia, which is also known as pseudo-pyloric gland metaplasia (PGM) or spasmolytic peptide-expressing mucosa (SPEM), which only affects the oxyntic glands $[23,24]$.

The histogenesis of SPEM is still debated and needs to be further addressed. Seminal experiments supported the hypothesis that SPEM originates (independently of stem cells) from "transdifferentiation" or "dedifferentiation" [25, 26]. Other putative sources [27, 28] include the progenitor cells located at the glandular neck, or a population of Troy-positive cells located at the bottom of the oxyntic glands. The idea of a possible transformation of SPEM into intestinalized epithelia is supported by molecular profiling studies and histological evidence of SPEM preceding the histological detection of oxyntic intestinalization by years. 
Table 1. Gastritis: histological classification (modified from El-Zimaity [15]); variants of (long-standing, non-self-limiting) gastritis that may result in atrophic changes are identified as " $\mathrm{A}$ "

\begin{tabular}{|c|c|c|c|}
\hline $\begin{array}{l}\text { Main etiological } \\
\text { category }\end{array}$ & $\begin{array}{l}\text { Pathogenic } \\
\text { mechanism }\end{array}$ & Agent & Specific agent \\
\hline \multirow[t]{7}{*}{ Environmental } & \multirow[t]{4}{*}{ Transmissible } & Parasitic & $\begin{array}{l}\text { Anisakiasis } \\
\text { Cryptosporidium } \\
\text { Strongyloides stercoralis }\end{array}$ \\
\hline & & Fungal & $\begin{array}{l}\text { Mucormycosis } \\
\text { Candidiasis } \\
\text { Actinomyces } \\
\text { Histoplasmosis }\end{array}$ \\
\hline & & Bacterial & $\begin{array}{l}\text { Helicobacter pylori (A) } \\
\text { Enterococcus } \\
\text { Treponema pallidum }\end{array}$ \\
\hline & & Viral & $\begin{array}{l}\text { Cytomegalovirus } \\
\text { Enterovirus } \\
\text { Epstein-Barr virus }\end{array}$ \\
\hline & \multirow[t]{2}{*}{ Not transmissible } & Chemical & $\begin{array}{l}\text { Endogenous (bile); } \\
\text { Exogenous (alcohol, NSAIDs, doxycycline, taxol, } \\
\text { lanthanum carbonate) }\end{array}$ \\
\hline & & Physical & Radiation \\
\hline & Unknown & & \\
\hline \multirow[t]{4}{*}{ Host-related } & \multirow{2}{*}{$\begin{array}{l}\text { Autoimmune } \\
\text { Immune-mediated }\end{array}$} & \multicolumn{2}{|c|}{ Diagnostic label } \\
\hline & & \multicolumn{2}{|c|}{$\begin{array}{l}\text { Autoimmune (A) } \\
\text { Allergic } \\
\text { Lymphocytic } \\
\text { Eosinophilic } \\
\text { Collagenous } \\
\text { Graft-versus-host disease } \\
\text { Congenital immune disorders }\end{array}$} \\
\hline & $\begin{array}{l}\text { Associated with systemic } \\
\text { diseases }\end{array}$ & \multicolumn{2}{|c|}{ Crohn's, vasculitis, sarcoidosis, ischemia } \\
\hline & Unknown & \multicolumn{2}{|c|}{ Stress-induced } \\
\hline
\end{tabular}

Both subtypes of metaplastic changes are included in the spectrum of gastric atrophy $[29,30]$.

The inclusion of other (minor) variants of metaplastic transformation (e.g. pseudo-pancreatic metaplasia) in the spectrum of atrophy is irrelevant. Any subtype of gastric atrophy may give rise to functional changes (in acid secretion or pepsinogen serum levels, for instance) and/or a "remodeling" of the intragastric microenvironment. There is increasing evidence to suggest that the "atrophy-associated" microbiome may be involved in promoting a cancerprone microenvironment. Such a picture reinforces the priority of assessing and quantifying gastric mucosal atrophy endoscopically and histologically, considering the whole spectrum of atrophy phenotypes, all of which might be 


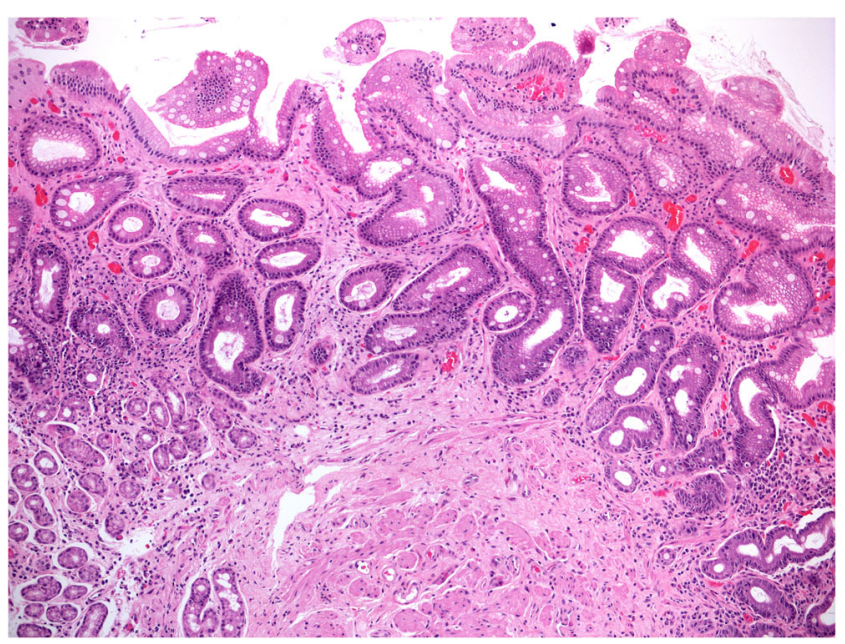

Fig. 3. Gastric mucosa atrophy: metaplastic variant. The largest portion of the biopsy sample (about $65 \%$; 0LGA score: 3 ) is covered by atrophic-metaplastic glands; goblet cells are the key marker of mucosal intestinalization. (Hematoxylin-eosin, original magnification $\times 5$ )

involved in creating cancer-promoting biological conditions. Taking this new approach, we need to reconsider the "traditional" view concerning the specific responsibility of intestinal metaplasia in gastric carcinogenesis, and return to a holistic concept of atrophy as the "cancerization field" for gastric adenocarcinoma [24, 31-36].

\section{Gastritis: Biopsy sampling protocols and histological assessments}

The rationale behind gastric biopsy sampling takes into account the physiopathological compartmentalization of the gastric mucosa. Already in embryo, the gastric sac consists of two (functional, histological) compartments, and they remain distinct after birth.

\section{Gastric compartmentalization (from the embryo to the adult)}

There is a paucity of (sometimes contradictory) information on the characterization of the embryonic stomach: canonical Wnt signaling pathway is assumed to be virtually restricted to the cranial gastric segment and absent from the presumptive antrum. The distinctive profile of the embryonic stomach is supported by two recent complementary observations $[37,38]$ : the deletion of Ctnnb1, a canonical WNT-effector, is associated with ectopic $P d x 1$ expression, which results in cranial stomach antralization; and the deletion of Bapx1 (a transcription factor expressed in the mesenchyme of the distal stomach) results in an "oxyntic transformation" of the antral stomach (Fig. 4).

At birth, there are two main, histologically distinct gastric mucosal compartments: the oxyntic (corpus) mucosa, and the mucosecreting (antral) mucosa. A third area covers a narrow portion of the junctional area between the terminal esophagus and the most cranial segment of the stomach. The phenotype of native cardia-mucosa is still controversial. Equally credited theories support a 


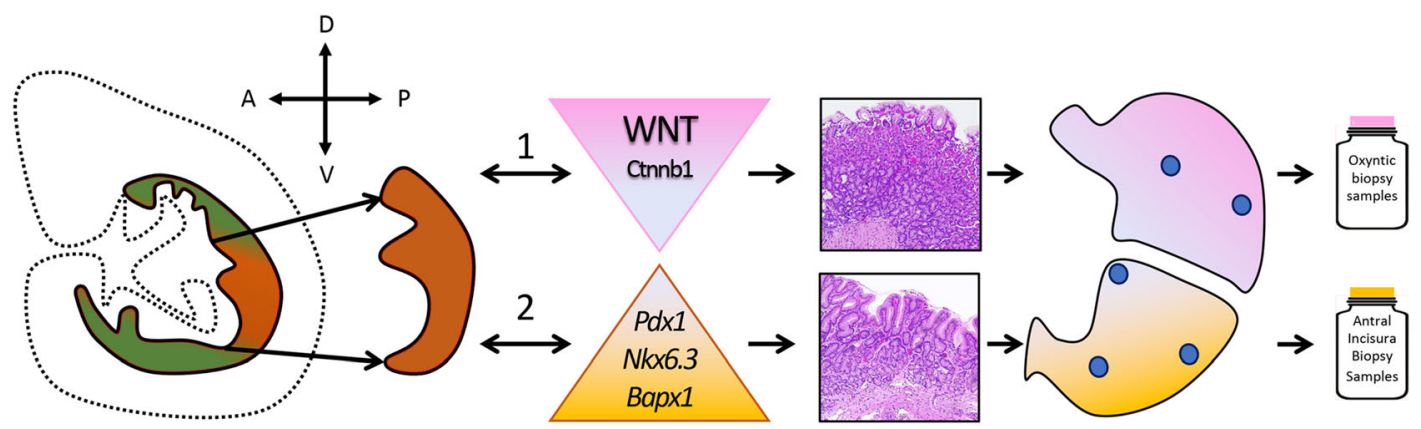

1. WNT-mediated gastric patterning mechanisms: WNT/beta-catenin signaling promotes oxyntic specification; 2. Transcription factors as $P d \times 1, N k \times 6.3$, and Bapx1 (as expressed in mesenchyme surrounding the distal stomach) are specifically involved in promoting the the caudal specification (mucosecreting antral mucosa). Abbreviations A: anterior; P: posterior; V: ventral; D: dorsal. ${ }^{36,37}$

Fig. 4. 1. WNT-mediated gastric patterning mechanisms: WNT/beta-catenin signaling promotes oxyntic specification. 2. Transcription factors such as Pdx1, Nkx6.3, and Bapx1 (as expressed in mesenchyme surrounding the distal stomach) are specifically involved in promoting the caudal specification (mucosecreting antral mucosa). Abbreviations A: anterior; P: posterior; V: ventral; D: dorsal $[36,37]$

glandular population including both native mucosecreting (antral type) and native oxyntic glands, or a mucosa natively consisting only of native oxyntic glands, with any mucosecreting component considered a metaplastic transformation of the resident oxyntic glands.

Distally to the cardia, the largest portion of the gastric mucosa consists of oxyntic glands (including chief, parietal end enterochromaffin-like [ECL] cells). The so-called atrophic border, better defined as the pyloric-fundic gland border, is an irregular boundary between the oxyntic and the mucosecreting compartments. The latter compartment consists of coiled mucosecreting glands extending from approximately two-thirds of the length of the stomach hook to the pyloric sphincter. The normal morphology of these areas is well established and easily recognizable. All these anatomical landmarks have important implications in the endoscopic and histological assessment of gastritis.

\section{Obtaining gastric mucosa biopsy samples: The biological rationale}

The different embryonic "patterning" and the post-natal histology and function of the stomach lend further support to the view of this organ as "two functions in one sac." This compartmentalization provides the rationale for obtaining gastric biopsy samples representative of both mucosal compartments. In routine endoscopic practice, however, this recommendation is frequently ignored, for two main reasons: the increasing costs of the diagnostic procedure associated with obtaining, handling, and assessing multiple biopsy samples; and a preference for using one (or even more!) biopsy samples for a rapid assessment of Helicobacter pylori status.

Different protocols for the endoscopic biopsy sampling of the gastric mucosa have been proposed, but they all recommend obtaining samples from both the oxyntic and the mucosecreting mucosa. The recommended number of specimens to collect varies, depending on the clinical indication, and the aims 
of the endoscopy/biopsy procedure. In general, more extensive biopsy protocols are recommended for research purposes, while a minimum set of gastric biopsies is suggested for clinical purposes. The most widely applied clinical protocol is the updated Sydney System, which includes a total of five biopsy specimens, i.e. two from the oxyntic mucosa (both submitted in the same vial), one from the incisura angularis, and two from the antral mucosa (all three submitted in the same vial). Any focal lesions should also be sampled and submitted separately $[8,39,40 \bullet 41]$.

\section{Gastritis: The clinical value of a "structured" histology report}

Gastric mucosal atrophy is recognized as the cancerization field in which more than $90 \%$ of gastric epithelial malignancies will eventually develop. This wellestablished evidence provides the rationale for assessing patients' "individual" gastric cancer risk from their histological atrophy score, which also takes its topography (corpus, antrum, or both) into account. Consistent with this approach, histological gastritis staging has proved a reliable predictor of gastric cancer risk.

In East Asian countries, the extent of atrophy and its associated cancer risk continues to be assessed endoscopically according to the Kimura-Takemoto classification [42-44]. In the Western world, a biopsy-based assessment is recommended (Maastricht V, MAPS guidelines). OLGA (Operative Link for Gastritis Assessment) is a validated staging system that considers both the atrophy score and the compartment (oxyntic versus mucosecreting) from which the biopsy samples were obtained (i.e. oxyntic and antral mucosa, according to the Sydney System protocol) $[45,46]$. The combined antral and oxyntic scores (see Table 2 for atrophy scoring and staging) result in a "gastritis stage" (from 0 to IV) indicating the risk of malignancy. An alternative staging system called OLGIM (Operative Link on Gastric Intestinal Metaplasia) is based only on a score for intestinal metaplasia $[47,48]$, and this makes it likely to be less sensitive in assessing atrophy than the (more comprehensive) OLGA approach [48].

Whenever possible, histological staging should be complemented with etiological information, reference to clinical parameters, and other diagnostic

Table 2. Gastritis staging system proposed by the Operative Link on Gastritis Assessment (OLGA)

\begin{tabular}{|c|c|c|c|c|c|}
\hline & & \multicolumn{4}{|c|}{$\begin{array}{l}\text { Corpus biopsy specimens } \\
\text { Overall atrophy score as assessed in biopsy samples } \\
\text { from oxyntic mucosa }\end{array}$} \\
\hline & & Score 0 & Score 1 & Score 2 & Score 3 \\
\hline \multirow{4}{*}{$\begin{array}{l}\text { Antrum/angularis biopsy specimens } \\
\text { Overall atrophy score as assessed in biopsy samples } \\
\text { from the antrum and angularis incisura }\end{array}$} & Score 0 & Stage 0 & Stage I & Stage II & Stage II \\
\hline & Score 1 & Stage I & Stage I & Stage II & Stage III \\
\hline & Score 2 & Stage II & Stage II & Stage III & Stage IV \\
\hline & Score 3 & Stage III & Stage III & Stage IV & Stage IV \\
\hline \multicolumn{6}{|c|}{$\begin{array}{l}\text { Scores for "global atrophy" (including non-metaplastic and metaplastic [IM \& SPEM] subtypes) to be applied to the mucosecreting (antral/ } \\
\text { angularis) and oxyntic (corpus/fundic) compartments. Atrophy score: Score } 0=\text { no atrophy in any of the specimens obtained from the same } \\
\text { compartment; Score } 1=\text { atrophy involving } 1-30 \% \text { of the specimens obtained from the same compartment; Score } 2=\text { atrophy involving } 31-60 \% \\
\text { of the specimens obtained from the same compartment; Score } 3=\text { atrophy involving }>60 \% \text { of the specimens obtained from the same } \\
\text { compartment }\end{array}$} \\
\hline
\end{tabular}


details. Table 1 lists all the relevant etiological factors, and those most often resulting in atrophic mucosal changes.

\section{From the histology report to the clinical patient's management}

In spite of the enormous progress made in endoscopic imaging technologies, with more to come, histology remains the gold standard for the diagnosis of gastritis. Advances in this area relate to an etiology-based diagnosis, already reflected in the new International Classification of Diseases (ICD-11), and to the clinical priority of gastritis staging in the long-term personalized management of gastritis patients. Relying on essential information about the etiology and staging of a case of gastritis, clinicians can safely proceed with the most appropriate therapy, and decide whether and what type of follow-up is required $[49,50]$.

Having identified the cause of gastritis, the first step will be to eliminate the noxious agent whenever possible. In cases of $H$. pylori gastritis, eradication therapy is recommended in all international consensus and guideline reports $[11 \bullet \bullet, 51,52]$.

In the absence of severe gastric disease and/or preneoplastic changes, the success of $H$. pylori eradication therapy can be tested with a noninvasive surrogate marker (urea breath test [UBT], fecal antigen test). A negative test result indicates the healing of $H$. pylori gastritis [53••]. Any specific infectious agent detected can be cured by appropriate antibiotic or antiviral treatments. No etiological therapy is available as yet for autoimmune gastritis, the clinical impact of which is constantly increasing all over the industrialized world. There is little evidence for glucocorticoid therapy to reverse the atrophy involved [54]. When pernicious anemia ensues, vitamin B12 supplementation is indicated. In the autoimmune setting, the (consistently recognized) risk of neuroendocrine neoplasia makes it important to adopt an appropriate staging system that includes IM-negative atrophic transformation (i.e. pseudo-pyloric metaplasia, or what is known as SPEM) [55, 56]. SPEM is involved in hyperplastic/ dysplastic ECL cell proliferation, and may theoretically be associated with a higher risk of gastric adenocarcinoma $[25,57,58]$. It is often more difficult to document the etiology of other forms of gastritis, but it may help to look for a systemic cause, as in Crohn's disease (Fig. 5).

Leaving aside the etiology of gastritis, a histology report plainly expressing the "level of alarm" related to the severity of atrophic disease (and its associated cancer risk, in particular) could contribute to generating treatment and followup protocols tailored to individual patients' clinical needs. This approach has been extensively applied in oncological practice and is the reasoning on which gastritis staging is based. In patients with "advanced" atrophic changes (highrisk OLGA/OLGIM stages III/IV), regular endoscopic follow-up serves the fundamental purpose of a reliable secondary gastric cancer prevention strategy [59].

Three different trials with a follow-up spanning several years produced significant evidence to support a high risk of gastric cancer developing in patients with OLGA stages III/IV (Table 3) [40•, 60, 61••]. Two of these three studies $[40 \bullet, 61 \bullet \bullet$ were conducted in populations of consecutive dyspeptic patients undergoing endoscopy, with no histological evidence of neoplastic 


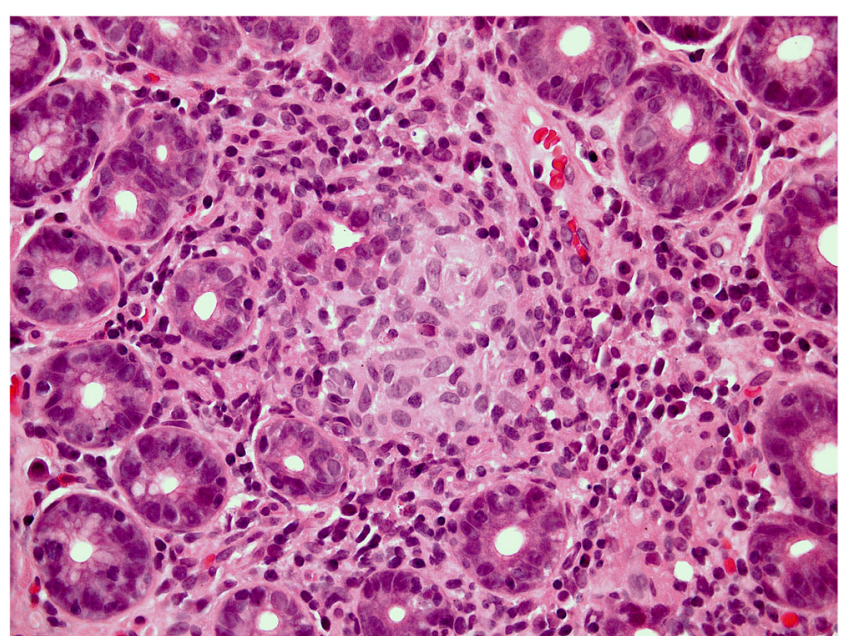

Fig. 5. Epithelioid granuloma in Crohn-associated gastritis. Infectious etiology was excluded by both molecular biology testing and special stain for Koch's bacilli. (Hematoxylin-eosin, original magnification $\times 40$ )

lesions (intraepithelial [IEN] or invasive gastric cancer [GC]). The studies had a similar patient distribution by stage, and the proportion of patients in stages III and IV never exceeded 3\% (these patients were mainly males, and their median age was older than that of patients with stage $0 / \mathrm{I} / \mathrm{II}$ disease). Such a low prevalence of patients "at risk" makes it feasible to implement dedicated programs of active surveillance. The two studies (involving 9191 patients in all) also consistently showed a dichotomous cancer risk, which was nil or negligible for stages 0/I/ II (low-risk stages) and high for OLGA stages III/IV (high-risk stages).

The third study [60] involved 93 patients who were followed up with paired endoscopies for more than 12 years (range: 144-204 months). It was conducted on a population living in a mountain valley previously identified as being at high risk of GC (with an incidence of gastric malignancy of 270/100,000/ 5 years, and an $80 \%$ prevalence of $H$. pylori). As expected in this particular epidemiological context, the prevalence of high-risk stages was greater than in the two previously mentioned studies, but all the incident neoplastic lesions (detected by the end of the follow-up) were identified among patients enrolled with stage III/IV gastritis.

The high risk of cancer developing in such cases enables us to identify patients early enough in their progression to gastric malignancy for timely intervention, which involves endoscopic resection of crucial areas of the stomach showing signs of early gastric cancer. Further adjunctive evidence significantly links high-risk OLGA gastritis with $H$. pylori status, but eradication therapies may be ineffective in the more advanced stages of gastritis (particularly when it is already associated with intraepithelial neoplastic lesions, with male gender, or with advanced age) $[41,62,63]$.

Histological staging should be combined with other information (family history, serology, endoscopy) to enable follow-up schedules to be tailored to a given patient's clinical and pathological profile [64]. Even in patients with early gastric cancer, further progression can be stopped by adequate management of their gastritis, as shown in the Korean study by Choi [65]. 
Table 3. Gastric cancer risk associated with OLGA stages of gastritis

\begin{tabular}{|c|c|c|c|c|}
\hline $\begin{array}{l}\text { OLGA } \\
\text { stage } \\
\text { of gastritis } \\
\text { (\%) at } \\
\text { enrollment }\end{array}$ & $\begin{array}{l}\text { Follow-up in months: } \\
\text { mean (range) }\end{array}$ & $\begin{array}{l}\text { Incident } \\
\text { neoplasia }\end{array}$ & $\begin{array}{l}\text { Incident neoplasia: } \\
\text { rate } / 10^{3} \text { person-years } \\
\text { (neoplastic lesions include both } \\
\text { intraepithelial and infiltrating } \\
\text { types) }\end{array}$ & $\begin{array}{l}95 \% \\
\text { Confidence } \\
\text { interval }\end{array}$ \\
\hline $0(80.8 \%)$ & $\begin{array}{l}53.6 \\
(76.6-79.2)\end{array}$ & $1 / 6005$ & Rate $/ 10^{3}$ person-years $=0.03$ & $0.004-0.19$ \\
\hline I $(12.6 \%)$ & $\begin{array}{l}53.6 \\
(76.6-79.2)\end{array}$ & $2 / 934$ & Rate $/ 10^{3}$ person-years $=0.34$ & $0.09-1.36$ \\
\hline II $(4.3 \%)$ & $\begin{array}{l}38.6 \\
(76.6-79.2)\end{array}$ & $3 / 322$ & Rate $/ 10^{3}$ person-years $=1.48$ & $0.48-4.58$ \\
\hline III $(2.0 \%)$ & $\begin{array}{l}35.5 \\
(70.8-74,4)\end{array}$ & $17 / 152$ & Rate $/ 10^{3}$ person-years $=19.1$ & $11.9-30.7$ \\
\hline IV $(0.3 \%)$ & $\begin{array}{l}39.4 \\
(63.6-63.6)\end{array}$ & $5 / 23$ & Rate $/ 10^{3}$ person-years $=41.2$ & $17.2-99.3$ \\
\hline Patients & $\begin{array}{l}\text { considered } \\
7436^{40} \\
10^{3} / \text { person-years = } \\
0.60\end{array}$ & $\begin{array}{c}52.7 \\
(11.573 .0)\end{array}$ & $\begin{array}{l}\text { LG-IEN = } 17 \\
\text { HG-IEN = } 4 \\
G C=7\end{array}$ & Rate \\
\hline $\begin{array}{l}0(77.6 \%) \\
\text { I }(14.4 \%)\end{array}$ & $\begin{array}{l}53.6 \\
(11.5-70.3)\end{array}$ & $\begin{array}{l}0 / 1362 \\
0 / 253\end{array}$ & Rate $/ 10^{3}$ person-years $=0.0$ & $0-0.4$ \\
\hline II $(5.1 \%)$ & $\begin{array}{l}38.6 \\
(5.9-64.3)\end{array}$ & $0 / 88$ & & \\
\hline III $(2.1 \%)$ & $\begin{array}{l}35.5 \\
(15.8-60.7)\end{array}$ & $4 / 37$ & Rate $/ 10^{3}$ person-years $=36.5$ & $13.7-97.4$ \\
\hline IV $(0.85 \%)$ & $\begin{array}{l}34.8 \\
(23.3-58.1)\end{array}$ & $3 / 15$ & Rate $/ 10^{3}$ person-years $=63.1$ & $20.3-195.6$ \\
\hline Patients & $\begin{array}{l}\text { considered } \\
1755^{61}\end{array}$ & & $\begin{array}{l}\text { LG-IEN = } \\
\text { HG-IEN = } 1 \\
G C=2\end{array}$ & \\
\hline \multirow[t]{4}{*}{0} & $(62.3 .6 \%)$ & \multirow{4}{*}{$\begin{array}{c}149 \\
(144-204)\end{array}$} & $0 / 58$ & \multirow[b]{4}{*}{$\begin{array}{l}\text { OLGA stages } \\
\text { III/IV (as } \\
\text { assessed at ini- } \\
\text { tial biopsy) } \\
\text { were associat- } \\
\text { ed with a sig- } \\
\text { nificantly } \\
\text { higher risk of } \\
\text { GC (at end of } \\
\text { follow-up) } \\
\text { than stages } \\
\text { 0/I/II } \\
\text { (Kaplan-Maier } \\
\text { log-rank test; } \\
\text { p = 0.0001; } \\
\text { RR = 58.00; } \\
95 \% \text { CI = }\end{array}$} \\
\hline & I $(17.2 \%)$ & & $0 / 16$ & \\
\hline & II $(9.6 \%)$ & & $0 / 9$ & \\
\hline & III $(6.4 \%)$ & & $2 / 6$ & \\
\hline
\end{tabular}


Table 3. (Continued)

\begin{tabular}{|c|c|c|c|c|}
\hline \multirow[t]{3}{*}{$\begin{array}{l}\text { OLGA } \\
\text { stage } \\
\text { of gastritis } \\
\text { (\%) at } \\
\text { enrollment }\end{array}$} & $\begin{array}{l}\text { Follow-up in months: } \\
\text { mean (range) }\end{array}$ & $\begin{array}{l}\text { Incident } \\
\text { neoplasia }\end{array}$ & $\begin{array}{l}\text { Incident neoplasia: } \\
\text { rate } / 10^{3} \text { person-years } \\
\text { (neoplastic lesions include both } \\
\text { intraepithelial and infiltrating } \\
\text { types) }\end{array}$ & $\begin{array}{l}95 \% \\
\text { Confidence } \\
\text { interval }\end{array}$ \\
\hline & & & & $\begin{array}{l}5.67-592.5, p \\
<0.001)\end{array}$ \\
\hline & IV $(4.3 \%)$ & $4 / 4$ & & \\
\hline Patients & $\begin{array}{l}\text { considered } \\
93^{60}\end{array}$ & & $\begin{array}{l}\text { IND-IEN }=2^{*} \\
\text { LG-IEN }=1^{*} \\
\text { HG-IEN }=1 \\
G C=2\end{array}$ & $\begin{array}{l}\text { At follow-up } \\
\text { endoscopy, } 6 \\
\text { patients had } \\
\text { IEN or GC: } 2 \\
\text { were IND-IEN; } \\
1 \text { was a LG-IEN; } \\
1 \text { was HG-IEN; } \\
\text { and } 2 \text { were GC } \\
\text { (and } 1 \text { of them } \\
\text { had been en- } \\
\text { rolled as LG-- } \\
\text { IEN) } \\
\text { Study conducted in } \\
\text { a mountain area } \\
\text { considered at high } \\
\text { risk of GC }\end{array}$ \\
\hline $\begin{array}{l}\text { The table sum } \\
\text { epidemiologic } \\
\text { acting as add } \\
\text { grade; } \mathrm{HG}=\mathrm{h}\end{array}$ & $\begin{array}{l}\text { s the crude numbers obtain } \\
\text { ing, } H \text {. pylori status, inclu } \\
\text { risk factors) is not shown } \\
\text { de; } \mathrm{GC}=\text { invasive gastric ca }\end{array}$ & $\begin{array}{l}\text { g-term fo } \\
\text { bacteriu } \\
\text { ntra-epith }\end{array}$ & $\begin{array}{l}\text { studies. The clinical impact of crucial variz } \\
\text { ence, patient's gender and age, and oth } \\
\text { oplasia; IND-IEN = indefinite for intra-ep }\end{array}$ & $\begin{array}{l}\text { linical family history, } \\
\text { orbidities potentially } \\
\text { neoplasia; LG = low- }\end{array}$ \\
\hline
\end{tabular}

As mentioned earlier, gastric (atrophic) intestinalization only accounts for one of the three "faces" of the atrophic transformation of the mucosa. Restricting the atrophy score to IM alone (as in the OLGIM approach) can have significant drawbacks in terms of a conclusive staging of gastritis, ultimately excluding patients who warrant a "dedicated" secondary prevention strategy from an appropriate follow-up program [13]. The updated endoscopic guidelines for managing gastritis fully embrace recent progress and the clinical relevance of proper gastritis staging for the purpose of cancer prevention [42].

\section{Outlook into 2020}

According to the Kyoto Global Consensus Conference, etiology is taken for reference in the classification of gastritis. The etiological picture of longstanding gastritis can include both environmental (e.g. H. pylori) and hostrelated (e.g. Autoimmunity) agents, potentially resulting in the atrophic transformation of native gastric mucosa. Epidemiological evidence implicates the atrophic microenvironment in $\mathrm{H}$. pylori gastritis as a major factor responsible for the etiopathogenesis of more than $90 \%$ of gastric malignancies. 
The atrophic transformation of gastric mucosa gives rise to different histological phenotypes, all of which have been biologically profiled and can be histologically scored. They may also be associated with a range of functional changes, which can serve as (quantitative) serological markers of the atrophic process. It is easy to imagine the atrophy-remodeled gastric microbiota having a role as co-promoter in the atrophic cancer-prone microenvironment.

In Western countries, histology-based gastritis staging (with the OLGA system) has consistently proved reliable in predicting the cancer risk associated with atrophy. Any (complementary) endoscopy-based risk assessment (as suggested in authoritative literature) is also welcome. The reliability of endoscopic staging still needs to be supported by large-scale studies, however, and validated in terms of its clinical reproducibility.

Over the coming years, we will see how this multidisciplinary approach can be optimized for the purpose of designing global strategies for eradicating gastric cancer and implementing patient-tailored prevention strategies. The available evidence does suggest that combining primary and secondary prevention strategies can realistically succeed in cutting the epidemiological impact of gastric cancer - the world's fourth leading cause of cancer-related death.

\section{Funding Information}

Open access funding provided by Università degli Studi di Padova within the CRUI-CARE Agreement. This work was partly supported by grants from the Italian Association for Cancer Research (AIRC Regional grant no. 6421 to MR).

\section{Compliance with ethical standards}

\section{Conflict of interest}

Massimo Rugge, Kentaro Sugano, Diana Sacchi, Marta Sbaraglia, and Peter Malfertheiner declare no conflict of interest.

Human and animal rights and informed consent

This article does not contain any studies with human or animal subjects performed by any of the authors.

Open Access This article is licensed under a Creative Commons Attribution 4.0 International License, which permits use, sharing, adaptation, distribution and reproduction in any medium or format, as long as you give appropriate credit to the original author(s) and the source, provide a link to the Creative Commons licence, and indicate if changes were made. The images or other third party material in this article are included in the article's Creative Commons licence, unless indicated otherwise in a credit line to the material. If material is not included in the article's Creative Commons licence and your intended use is not permitted by statutory regulation or exceeds the permitted use, you will need to obtain permission directly from the copyright holder. To view a copy of this licence, visit http://creativecommons.org/licenses/by/4.0/. 


\section{References and Recommended Reading}

Papers of particular interest, published recently, have been highlighted as:

- Of importance

- Of major importance

1. Talley NJ. Editorial: moving away from focussing on gastric pathophysiology in functional dyspepsia: new insights and therapeutic implications. Am J

Gastroenterol. 2017;112(1):141-4. https://doi.org/10. 1038/ajg.2016.519.

2. Miwa H, Oshima T, Tomita T, et al. Recent understanding of the pathophysiology of functional dyspepsia: role of the duodenum as the pathogenic center. J Gastroenterol. 2019;54(4):305-11. https://doi.org/ 10.1007/s00535-019-01550-4.

3. Okamura T, Iwaya Y, Kitahara K, Suga T, Tanaka E. Accuracy of endoscopic diagnosis for mild atrophic gastritis infected with Helicobacter pylori. Clin Endosc. 2018;51(4):362-7. https://doi.org/10.5946/ce.2017. 177.

4. Fukuda H, Miura Y, Osawa H, et al. Linked color imaging can enhance recognition of early gastric cancer by high color contrast to surrounding gastric intestinal metaplasia. J Gastroenterol. 2019;54(5):396-406. https:/doi.org/10.1007/s00535-018-1515-6.

5. Takeda T, Asaoka D, Nojiri S, et al. Linked color imaging and the Kyoto classification of gastritis: evaluation of visibility and inter-Rater reliability. Digestion. 2019:1-10. https://doi.org/10.1159/000501534.

6. Sun X, Bi Y, Nong B, et al. Linked color imaging confers benefits in profiling $H$. pylori infection in the stomach. Endosc Int open. 2019;7(7):E885-92. https://doi.org/ 10.1055/a-0895-5377.

7. Dohi O, Majima A, Naito Y, et al. Can image-enhanced endoscopy improve the diagnosis of Kyoto classification of gastritis in the clinical setting? Dig Endosc. 2019:den.13540. https://doi.org/10.1111/den.13540.

8. Rugge M, Fassan M, Tsukanov VV, Meggio A, de Boni $M$. From open-type atrophic gastritis to gastritis staging. Dig Dis Sci. 2011;56(6):1917-8. https://doi.org/ 10.1007/s10620-011-1705-z.

9. Mizukami K, Ogawa R, Okamoto K, et al. Objective endoscopic analysis with linked color imaging regarding gastric mucosal atrophy: a pilot study. Gastroenterol Res Pract. 2017;2017:5054237. https:// doi.org/10.1155/2017/5054237.

10. White JR, Sami SS, Reddiar D, et al. Narrow band imaging and serology in the assessment of premalignant gastric pathology. Scand J Gastroenterol. 2018;53(12):1611-8. https://doi.org/10.1080/ 00365521.2018 .1542455 .

11.• Sugano K, Tack J, Kuipers EJ, et al. Kyoto global consensus report on Helicobacter pylori gastritis. Gut. 2015;64(9):1353-67. https://doi.org/10.1136/gutjnl2015-309252.
The publication refers the results of a global consensus concerning the taxonomy of gastritis.

12. Mahachai V, Vilaichone R-K, Pittayanon $\mathrm{R}$, et al. Helicobacter pylori management in ASEAN: the Bangkok consensus report. J Gastroenterol Hepatol. 2018;33(1):37-56. https://doi.org/10.1111/jgh. 13911.

13. Rugge M, Sugano K, Scarpignato C, Sacchi D, Oblitas WJ, Naccarato AG. Gastric cancer prevention targeted on risk assessment: gastritis OLGA staging. Helicobacter. 2019;24(2):e12571. https://doi.org/10. 1111/hel.12571.

14. Hunt RH, Camilleri $M$, Crowe SE, et al. The stomach in health and disease. Gut. 2015;64(10):1650-68. https://doi.org/10.1136/gutjnl-2014-307595.

15. El-Zimaity H, Choi W-T, Lauwers GY, Riddell R. The differential diagnosis of Helicobacter pylori negative gastritis. Virchows Arch. 2018;473(5):533-50. https:// doi.org/10.1007/s00428-018-2454-6.

16. Choi W-T, Lauwers GY. Patterns of gastric injury: beyond Helicobacter pylori. Surg Pathol Clin. 2017;10(4):801-22. https://doi.org/10.1016/j.path. 2017.07.003.

17. Weinstein R, Riordan MA, Wenc K, Kreczko S, Zhou M, Dainiak N. Dual role of fibronectin in hematopoietic differentiation. Blood. 1989;73(1):111-6. http://www. ncbi.nlm.nih.gov/pubmed/2910353. Accessed 19 Nov 2019.

18. Nordenstedt H, Graham DY, Kramer JR, et al. Helicobacter pylori-negative gastritis: prevalence and risk factors. Am J Gastroenterol. 2013;108(1):65-71. https://doi.org/10.1038/ajg.2012.372.

19. Shiota S, Thrift AP, Green L, et al. Clinical manifestations of Helicobacter pylori-negative gastritis. Clin Gastroenterol Hepatol. 2017;15(7):1037-1046.e3. https://doi.org/10.1016/j.cgh.2017.01.006.

20. Rugge M, Genta RM, Di Mario F, et al. Gastric cancer as preventable disease. Clin Gastroenterol Hepatol. 2017;15(12):1833-43. https://doi.org/10.1016/j.cgh. 2017.05.023.

This comprehensive review provides the biological and clinical rationale for gastric cancer prevention strategies.

21. Ruiz B, Garay J, Johnson W, et al. Morphometric assessment of gastric antral atrophy: comparison with visual evaluation. Histopathology. 2001;39(3):23542. https://doi.org/10.1046/j.1365-2559.2001.01221. $\mathrm{x}$.

22. Rugge M, Correa P, Dixon MF, et al. Gastric mucosal atrophy: interobserver consistency using new criteria for classification and grading. Aliment Pharmacol Ther. 
2002;16(7):1249-59. https://doi.org/10.1046/j.13652036.2002.01301.x.

23. Zambon C-F, Basso D, Navaglia F, et al. Helicobacter pylori virulence genes and host IL-1RN and IL-1beta genes interplay in favouring the development of peptic ulcer and intestinal metaplasia. Cytokine.

2002;18(5):242-51. https://doi.org/10.1006/cyto. 2002.0891.

24. Graham DY, Rugge M, Genta RM. Diagnosis: gastric intestinal metaplasia - what to do next? Curr Opin Gastroenterol. 2019;35(6):535-43. https://doi.org/10. 1097/MOG.0000000000000576.

25. Goldenring JR. Pyloric metaplasia, pseudopyloric metaplasia, ulcer-associated cell lineage and spasmolytic polypeptide-expressing metaplasia: reparative lineages in the gastrointestinal mucosa. J Pathol. 2018;245(2):132-7. https://doi.org/10.1002/path. 5066.

26. Radyk MD, Burclaff J, Willet SG, Mills JC. Metaplastic cells in the stomach arise, independently of stem cells, via dedifferentiation or transdifferentiation of chief cells. Gastroenterology. 2018;154(4):839-843.e2. https://doi.org/10.1053/j.gastro.2017.11.278.

27. Hayakawa Y, Ariyama H, Stancikova J, et al. Mist1 expressing gastric stem cells maintain the normal and neoplastic gastric epithelium and are supported by a perivascular stem cell niche. Cancer Cell.

2015;28(6):800-14. https://doi.org/10.1016/j.ccell. 2015.10.003.

28. Hayakawa Y, Fox JG, Wang TC. Isthmus stem cells are the origins of metaplasia in the gastric corpus. Cell Mol Gastroenterol Hepatol. 2017;4(1):89-94. https://doi. org/10.1016/j.jcmgh.2017.02.009.

29. Rugge M, Pennelli G, Pilozzi E, et al. Gastritis: the histology report. Dig Liver Dis. 2011;43(Suppl 4):S373-84. https://doi.org/10.1016/S1590-8658(11) 60593-8.

30. Rugge M, Correa P, Di Mario F, et al. OLGA staging for gastritis: a tutorial. Dig Liver Dis. 2008;40(8):650-8. https://doi.org/10.1016/j.dld.2008.02.030.

31. Parsons BN, Ijaz UZ, D'Amore R, et al. Comparison of the human gastric microbiota in hypochlorhydric states arising as a result of Helicobacter pylori-induced atrophic gastritis, autoimmune atrophic gastritis and proton pump inhibitor use. PLoS Pathog. 2017;13(11):e1006653. https://doi.org/10.1371/ journal.ppat.1006653.

32. Badal VD, Wright D, Katsis $\mathrm{Y}$, et al. Challenges in the construction of knowledge bases for human microbiome-disease associations. Microbiome. 2019;7(1):129. https://doi.org/10.1186/s40168-0190742-2.

33. Park CH, Lee A-R, Lee Y-R, Eun CS, Lee SK, Han DS. Evaluation of gastric microbiome and metagenomic function in patients with intestinal metaplasia using $16 \mathrm{~S}$ rRNA gene sequencing. Helicobacter. 2019;24(1):e12547. https://doi.org/10.1111/hel. 12547.
34. Del Prete A, Allavena P, Santoro G, Fumarulo R, Corsi $\mathrm{MM}$, Mantovani A. Molecular pathways in cancerrelated inflammation. Biochem Medica. 2011:264-75. https://doi.org/10.11613/BM.2011.036.

35. Iino C, Shimoyama T, Chinda D, Sakuraba H, Fukuda S, Nakaji S. Influence of Helicobacter pylori infection and atrophic gastritis on the gut microbiota in a Japanese population. Digestion. 2019:1-11. https://doi.org/10. 1159/000500634.

36. McDonald SAC, Greaves LC, Gutierrez-Gonzalez L, et al. Mechanisms of field cancerization in the human stomach: the expansion and spread of mutated gastric stem cells. Gastroenterology. 2008;134(2):500-10. https://doi.org/10.1053/j.gastro.2007.11.035.

37. McCracken KW, Wells JM. Mechanisms of embryonic stomach development. Semin Cell Dev Biol. 2017;66:36-42. https://doi.org/10.1016/j.semcdb. 2017.02.004.

38. Thompson CA, DeLaForest A, Battle MA. Patterning the gastrointestinal epithelium to confer regional-specific functions. Dev Biol. 2018;435(2):97-108. https://doi. org/10.1016/j.ydbio.2018.01.006.

39. Malfertheiner P, Megraud F, O'Morain CA, et al. Management of Helicobacter pylori infection-the Maastricht V/Florence consensus report. Gut. 2017;66(1):6-30. https://doi.org/10.1136/gutjnl-2016-312288.

40. Rugge M, Genta RM, Fassan M, et al. OLGA gastritis staging for the prediction of gastric cancer risk: a longterm follow-up study of 7436 patients. Am J Gastroenterol. 2018;113(11):1621-8. https://doi.org/ 10.1038/s41395-018-0353-8.

In this long-term follow-up study of 7436 patients, a significant increased risk of gastric cancer was only associated with patients harbouring OLGA stages III/IV at their enrollment.

41. Rugge M, Sacchi D, Graham DY, Genta RM. Secondary prevention of gastric cancer: merging the endoscopic atrophic border with OLGA staging. Gut. 2019:gutjnl2019-319107. https://doi.org/10.1136/gutjnl-2019319107.

42. Pimentel-Nunes P, Libânio D, Marcos-Pinto R, et al. Management of epithelial precancerous conditions and lesions in the stomach (MAPS II): European Society of Gastrointestinal Endoscopy (ESGE), European Helicobacter and Microbiota Study Group (EHMSG), European Society of Pathology (ESP), and Sociedade Portuguesa de Endoscopia Digestiva (SPED) guideline update 2019. Endoscopy. 2019;51(4):365-88. https:// doi.org/10.1055/a-0859-1883.

43. Kono S, Gotoda T, Yoshida S, et al. Can endoscopic atrophy predict histological atrophy? Historical study in United Kingdom and Japan. World J Gastroenterol. 2015;21(46):13113-23. https://doi.org/10.3748/wjg. v21.i46.13113.

44. Kimura K, Takemoto T. An endoscopic recognition of the atrophic border and its significance in chronic gastritis. Endoscopy. 1969;1(03):87-97. https://doi.org/ 10.1055/s-0028-1098086. 
45. Price AB. The Sydney system: histological division. J Gastroenterol Hepatol. 1991;6(3):209-22. https://doi. org/10.1111/j.1440-1746.1991.tb01468.x.

46. Rugge M, Meggio A, Pennelli G, et al. Gastritis staging in clinical practice: the OLGA staging system. Gut. 2007;56(5):631-6. https://doi.org/10.1136/gut.2006. 106666.

47. Capelle LG, de Vries AC, Haringsma J, et al. The staging of gastritis with the OLGA system by using intestinal metaplasia as an accurate alternative for atrophic gastritis. Gastrointest Endosc. 2010;71(7):1150-8. https://doi.org/10.1016/j.gie.2009.12.029.

48. Rugge $M$, Fassan $M$, Pizzi $M$, et al. Operative link for gastritis assessment vs operative link on intestinal metaplasia assessment. World J Gastroenterol. 2011;17(41):4596-601. https://doi.org/10.3748/wjg. v17.i41.4596.

49. Meggio A, Mariotti G, Gentilini M, de Pretis G. Priority and appropriateness of upper endoscopy out-patient referrals: two-period comparison in an open-access unit. Dig Liver Dis. 2019;51(11):1562-6. https://doi. org/10.1016/j.dld.2019.05.028.

50. Teriaky A, AlNasser A, McLean C, Gregor J, Yan B. The utility of endoscopic biopsies in patients with normal upper endoscopy. Can J Gastroenterol Hepatol. 2016;2016:3026563. https://doi.org/10.1155/2016/ 3026563.

51. Schulz C, Schütte K, Koch N, et al. The active bacterial assemblages of the upper GI tract in individuals with and without Helicobacter infection. Gut.

2018;67(2):216-25. https://doi.org/10.1136/gutjnl2016-312904.

52. Fallone CA, Moss SF, Malfertheiner P. Reconciliation of recent Helicobacter pylori treatment guidelines in a time of increasing resistance to antibiotics. Gastroenterology. 2019;157(1):44-53. https://doi.org/10.1053/j. gastro.2019.04.011.

53.• Malfertheiner P. Diagnostic methods for H. pylori infection: choices, opportunities and pitfalls. United Eur Gastroenterol J. 2015;3(5):429-31. https://doi.org/10. $1177 / 2050640615600968$. The review critically considers the different (non-invasive and invasive) methods clinically applied in the assessment of current Helicobacer pylori infection.

54. Jeffries GH, Todd JE, Sleisenger MH. The effect of prednisolone on gastric mucosal histology, gastric secretion, and vitamin B 12 absorption in patients with pernicious anemia. J Clin Invest. 1966;45(5):803-12. https://doi.org/10.1172/JCI105395.

55. Zhang M, Liu S, Hu Y, et al. Biopsy strategies for endoscopic screening of pre-malignant gastric lesions. Sci Rep. 2019;9(1):14909. https://doi.org/10.1038/ s41598-019-51487-0.

56. Isajevs S, Liepniece-Karele I, Janciauskas D, et al. Gastritis staging: interobserver agreement by applying OLGA and OLGIM systems. Virchows Arch.
2014;464(4):403-7. https://doi.org/10.1007/s00428014-1544-3.

57. Halldórsdóttir AM, Sigurdardóttrir M, Jónasson JG, et al. Spasmolytic polypeptide-expressing metaplasia (SPEM) associated with gastric cancer in Iceland. Dig Dis Sci. 2003;48(3):431-41. https://doi.org/10.1023/ a:1022564027468.

58. Koulis A, Buckle A, Boussioutas A. Premalignant lesions and gastric cancer: current understanding. World J Gastrointest Oncol. 2019;11(9):665-78. https://doi. org/10.4251/wjgo.v11.i9.665.

59. Nagtegaal ID, Odze RD, Klimstra D, et al. The 2019 WHO classification of tumours of the digestive system. Histopathology. 2019:his.13975. https://doi.org/10. 1111/his.13975.

60. Rugge M, de Boni M, Pennelli G, et al. Gastritis OLGAstaging and gastric cancer risk: a twelve-year clinicopathological follow-up study. Aliment Pharmacol Ther. 2010;31(10):1104-11. https://doi.org/10.1111/ j.1365-2036.2010.04277.x.

61.• Rugge M, Meggio A, Pravadelli C, et al. Gastritis staging in the endoscopic follow-up for the secondary prevention of gastric cancer: a 5-year prospective study of 1755 patients. Gut. 2019;68(1):11-7. https://doi.org/ 10.1136/gutjnl-2017-314600.

In a large cohort of 1755 dyspeptic outpatients undergoing upper gastrointestinal endoscopy, this long-term follow-up study provides evidence that a significant risk of neoplastic progression is only associated with patients harboring OLGA stages III/IV at their enrollment.

62. de Vries AC, Kuipers EJ, Rauws EAJ. Helicobacter pylori eradication and gastric cancer: when is the horse out of the barn? Am J Gastroenterol. 2009;104(6):1342-5. https://doi.org/10.1038/ajg.2008.15.

63. Rugge $M$, de Boni M, Pennelli G, Mescoli C, Graham DY. OLGA can guard the barn. Am J Gastroenterol. 2009;104(12):3099. author reply 3101-2. https://doi. org/10.1038/ajg.2009.512.

64. Genta RM, Rugge M. Gastric precancerous lesions: heading for an international consensus. Gut. 1999;45(Suppl 1):I5-8. http://www.ncbi.nlm.nih.gov/ pubmed/10457028.

65. Choi IJ, Kim Y-I, Park B. Helicobacter pylori and prevention of gastric cancer. N Engl J Med. 2018;378(23):2244-5. https://doi.org/10.1056/ NEJMc1805129.

\section{Publisher's Note}

Springer Nature remains neutral with regard to jurisdictional claims in published maps and institutional affiliations. 